\title{
Optimization of purslane plant using cooking and pickling processes for reducing oxalate content
}

\author{
Waleed, Z. Badawy ${ }^{1 *}$, Salwa, G. Arafa ${ }^{1}$ and Czakó, Mihály ${ }^{2}$ \\ ${ }^{1}$ Food Technology Department, Faculty of Agriculture, Kafrelsheikh University, Egypt, \\ ${ }^{2}$ Department of Biological Sciences, University of South Carolina, 715 Sumter St., Columbia, SC29208, USA
}

\begin{abstract}
Purslane (Portulaca oleracea) is an edible plant rich in beneficial nutrients. Chemical composition, mineral composition, fatty acids, total phenolic compounds and radical scavenging activity of purslane were determined. In addition, oxalate content of purslane was analyzed after cooking at three temperatures $\left(60,80\right.$ and $\left.100{ }^{\circ} \mathrm{C}\right)$ for different durations (5, 10, 15 and 20 minute), and pickling for various durations (3, 6 and 9 days). Fatty acid analysis, sensory evaluation and quality characteristics of biscuits fortified by purslane powder, after oxalate reduction treatment, were carried out. Ash, fiber, protein and fat contents of were $23.42,16.03,5.64$ and $5.30 \%$, respectively on dry matter basis. Of the elements, potassium had the highest concentration $(4694.0 \mathrm{mg} \mathrm{K} / 100 \mathrm{~g})$, while zinc was found in the lowest concentration $(0.93 \mathrm{mg} \mathrm{Zn/100g).} \mathrm{Total} \mathrm{phenolics} \mathrm{of} \mathrm{purslane} \mathrm{were} 193.22$ $\mathrm{mg} / 100 \mathrm{~g}$ gallic acid equivalent and radical scavenging activity was $87.29 \%$. The proportion of unsaturated fatty acids in purslane is high; linolenic acid represents $40.4 \%$ of total fatty acids. The soluble fraction of total oxalate in purslane cooked for 20 minutes at 60,80 and $100{ }^{\circ} \mathrm{C}$ were $34.65,19.84$ and $15.84 \%$, respectively. While after pickling for $0,3,6$ and 9 days, the soluble fraction of total oxalate of purslane was $47.80,36.23,25.60$ and 14.39 $\%$, respectively. Addition of purslane powder after oxalate reducing treatments improved the quality characteristics of wheat flour biscuits. Portulaca oleracea is a good source of minerals, nutrients, antioxidants and omega-3 fatty acids, especially for functional food and nutraceutical applications.
\end{abstract}

Keywords: Purslane, Oxalate, Cooking, Pickling

Subject Classification: Food Science

Method/Approach: Experimental

Date of Publication: 2018-08-30

DOI: https://doi.org/10.24297/jaa.v8i1.7525

ISSN: 2349-0837

Volume: 08 Issue: 01

Journal: Journal of Advances in Agriculture

Publisher: CIRWORLD

Website: https://cirworld.com

This work is licensed under a Creative Commons Attribution 4.0 International License 


\subsection{Introduction}

Portulaca oleracea L., commonly known as purslane, is a common, succulent annual plant in the Portulacaceae family. It is extensively distributed in tropical to temperate regions worldwide [1] and can be a weed. In the Middle Ages, it was known as "baqla hamqa" by the Arabs, which means "crazy plant" or "crazy", most likely because of the way the branches ramify and extend over the ground. Ancient Egyptians used purslane as a medicinal plant. It spread both into Arab countries and the Mediterranean Basin, all the way to Spain. In China, purslane has been used as a medicinal and food plant for thousands of years [2] . In recent years, it has been reevaluated as a potential "new crop" for its certain properties that distinguish it as one of the best vegetable sources of omega-3 fatty acids (linolenic acid) and for its high crude protein and water-soluble polysaccharide contents $[3,4]$.

Purslane is rich in nutrients including protein, carbohydrates, $\mathrm{K}, \mathrm{Ca}, \mathrm{Zn}$, and $\mathrm{Na}[5,6]$. The leaves and stems of purslane contain $23.47 \%$ crude protein, $5.26 \%$ fat, $40.67 \%$ fiber, and $22.66 \%$ ash [6]. The stems and leaves also have high calorie values, $303.9 \mathrm{Kcal} / 100 \mathrm{~g}$ dry mass.

Total phenolics content of purslane ranged from 127 to $478 \mathrm{mg} \mathrm{GAE} / 100 \mathrm{~g}$ (GAE = gallic acid equivalent) wet mass of plant, and 2,2-diphenyl-1-picrylhydrazyl (DPPH) scavenging activity ranged from 2.52 to $3.29 \mathrm{mg} / \mathrm{mL}$ [7]. Another study found 630 to $1737 \mathrm{mg} / \mathrm{g}$ total phenolics [8]. Furthermore, it was reported that antioxidant activity in purslane showed a significant negative linear correlation with oxalate content [9].

Several organic acids, including citric acid, fumaric acid, succinic acid, and oxalic acid are present in purslane [10]. The most abundant organic acid in purslane is oxalic acid. Oxalic acid can form insoluble oxalates with $\mathrm{Ca}$ and $\mathrm{Fe}$, reduce $\mathrm{Ca}$ and $\mathrm{Fe}$ bio-availability, and increase the incidence of kidney stone formation [11].

Purslane is a good source of $\alpha$-tocopherol, ascorbic acid, $\beta$-carotene, and glutathione, which through their abilities to neutralize free radicals can prevent certain disorders $[12,13]$. A recent study showed that purslane is also a rich source of omega-3 fatty acids, in particular $\alpha$-linolenic acid, which is important in preventing heart attacks and strengthening the immune system [14]. The acceptance of purslane as a green leafy vegetable may be limited, despite all of its nutritional values, because of its high oxalic acid content [15].

Purslane is commonly eaten raw in Mediterranean countries as a garnish or mixed into a salad because of its characteristic strong taste. Purslane is often eaten raw with yoghurt and is sometimes lightly blanched in a way similar to spinach, and preparation these ways likely result in reduction of soluble oxalates either by binding with calcium in the yoghurt or through leaching out in the cooking water [16]. The beneficial nutritional characteristics of purslane are underexploited in Western diets, but its relatively high oxalate content may limit its wider use, particularly by those with a tendency to form kidney stones. It was suggested that the consumption of purslane every day is inadvisable [17]. This paradoxical situation motivated this present study. Moreover, the proportions of soluble and insoluble oxalate actually absorbed when purslane is eaten with yoghurt or other garnishes such as coconut cream or coconut milk was unknown.

Oxalate can be found in soluble and insoluble forms in plants. Oxalic acid forms soluble salts with sodium, potassium and magnesium (sodium and potassium oxalate being more soluble than the magnesium salt), while calcium and iron form insoluble salts. Free oxalic acid also occurs in plants [18].

Preparation of purslane may influence the total and soluble oxalate left in the food. Pickled purslane is a less common but interesting garnish. Soaking in vinegar (which is acetic acid diluted in water) can reduce the levels of soluble oxalates in the tissue because they may leach out into the vinegar, which is usually discarded. Cooking can reduce the level of soluble oxalate of many common vegetables, but not the insoluble fraction, if the cooking water containing the leached soluble oxalate is discarded [19].

Therefore, the current study was aiming at estimating the chemical composition, minerals, fatty acids, phenolic compounds, and radical scavenging activity of purslane. In addition, the effects of cooking (for different times 
at various temperatures) and pickling (for different times) processes of purslane on oxalate content was studied. Furthermore, in a sensory evaluation, quality characteristics, and analysis of fatty acids were carried out in biscuits fortified with purslane powder with reduced oxalate content.

\subsection{Materials and Methods}

\subsection{Plant Material}

Purslane (Portulaca oleracea L.) was sourced from a farm in El-Hamol city, Kafr El-Sheikh Governorate during the 2017 season. Fresh purslane was cleaned, and all of the samples were crushed into powder by a plant grinder after drying at $60^{\circ} \mathrm{C}$ in a hot air oven at $60^{\circ} \mathrm{C}$. The powder was packed in polyethylene pouches and stored at ambient temperature for later analysis.

\subsection{Preparation of a Biscuit Product}

Biscuits were manufactured as described by [20]. The basic formula used in the preparation of biscuit was as follows: wheat flour combined with fat (butter), salt, sugar, baking powder, and milk in a quantity of 1000, 200, $20,66,1.5$ and $200 \mathrm{gm}$, respectively. For four different fortification levels with purslane, wheat flour was replaced with 3, 6, and $9 \%$ of purslane powder. The butter and sugar were gently mixed by hand for 10 minutes to form a homogeneous mass. The other dry powder ingredients were mixed with the previous homogenous mass. Water was added at $25^{\circ} \mathrm{C}$ as required to attain optimum consistency. The mixture was then mixed using automatic dough mixer (Moulinex type 278, France) at low speed ( $80 \mathrm{rpm}$ ) for $10 \mathrm{~min}$. The dough was measured out to about $8 \mathrm{~g}$ portions, shaped round and flat, and baked at $180^{\circ} \mathrm{C}$ for $15 \mathrm{~min}$. in an electric oven until brown color appeared on the biscuit surface, then cooled for one hour at room temperature $\left(25^{\circ} \mathrm{C}\right)$.

\subsection{Proximate Chemical Composition}

The moisture, crude oil, crude protein, crude fiber and total ash content of purslane plant and biscuits fortified with purslane were determined as described in [21]. The carbohydrate content was calculated as the difference.

\subsection{Determination of Mineral Composition of Purslane Powder}

Minerals were determined after wet ashing by $6 \mathrm{~N} \mathrm{HCl}$. Magnesium $(\mathrm{Mg})$, iron $(\mathrm{Fe})$, zinc $(\mathrm{Zn})$, manganese $(\mathrm{Mn})$, and copper $(\mathrm{Cu})$ were determined using an atomic absorption spectrophotometer (Zeiss FMD3). Sodium (Na), calcium (Ca), and potassium (K) were determined by a flame photometer. Phosphorus $(\mathrm{P})$ was estimated photometrically measuring absorbance at $650 \mathrm{~nm}$ after forming a phosphorus molybdate complex and using a spectrophotometer. Standard calibration curve was used according to [21].

\subsection{Determination of Fatty Acid Composition}

Fatty acid analyses were performed in the central laboratory of the Faculty of Agriculture, Alexandria University. Samples were hydrolyzed and analyzed using a GC Chromatograph, Model Shimadzu-4CM (PFE), equipped with a FID detector and glass column $2.5 \times 3 \mathrm{~mm}$ i.d., under the conditions used by [22].

\subsection{Oxalic Acid Determination}

Oxalate was determined according to [21]. Soluble oxalates were extracted with water at $70^{\circ} \mathrm{C}$ for 20 minutes. For total oxalates, one gram of the sample was weighed into a $100 \mathrm{ml}$ conical flask. A $75 \mathrm{ml}$ volume of $3 \mathrm{M}$ sulfuric acid $\left(\mathrm{H}_{2} \mathrm{SO}_{4}\right)$ was added and the mixture was carefully stirred intermittently with a magnetic stirred for about $1 \mathrm{~h}$ and then filtered using Whatman No.1 filter paper. An aliquot of $25 \mathrm{~m}$ extract was collected and titrated against hot $\left[80-90^{\circ} \mathrm{C}\right] 0.1 \mathrm{~N}$ potassium permanganate $\left(\mathrm{KMnO}_{4}\right)$ solution to the point when a faint pink color appeared that persisted for at least $30 \mathrm{~s}$. The concentration of oxalate in each sample was obtained from the calculation: $1 \mathrm{ml} 0.1 \mathrm{~N}$ permanganate is equivalent to $0.006303 \mathrm{~g}$ oxalate. 


\subsection{Identification and Determination of Phenolic Acids}

Phenolic acids of dried purslane powder extract were identified and determined using an HPLC apparatus following the method of [23]. Phenolic acids were extracted by mixing $1 \mathrm{~g}$ of sample with $10 \mathrm{ml}$ of methanol, then centrifuged at $1000 \mathrm{rpm}$ for $10 \mathrm{~min}$., and filtered through a $0.2 \mu \mathrm{m}$ Millipore membrane filter. About 1-3 $\mathrm{ml}$ were collected in a vial for the analysis. A $5 \mu \mathrm{l}$ aliquot of the extract was injected into an HPLC Hewlett Packard (series 1050) equipped with auto sampling injector and quaternary pump. The solvents (methanol and acetonitrile) were degassed, the ultraviolet (UV) detector was set at $280 \mathrm{~nm}$, and the column temperature was maintained at $35 \circ \mathrm{C}$. A gradient separation was performed using the mobile phases (methanol and acetonitrile) at flow rate of $1 \mathrm{ml} / \mathrm{min}$. Retention time and peak area were used to calculate the phenolic acid concentration using the HP data analysis software.

\subsection{Antioxidant Capacity}

Purslane extracts prepared for polyphenol analysis were also analyzed for their antioxidant capacity (AC). The AC was measured using the 2,2-diphenyl-1-picrylhydrazyl (DPPH) assay [24].

\subsection{Cooking and Pickling Conditions}

Cooking and pickling procedures followed those of [11]. Whole purslane plants were boiled ( $300 \mathrm{~g}$ fresh material was added to $500 \mathrm{ml}$ boiling tap water) for $5,10,15$, and 20 minutes. Since the cooking water is not used, this method of preparation is equivalent blanching. The cooked samples were then dried at $60^{\circ} \mathrm{C}$ and ground to a powder. Whole fresh purslane plants were pickled by adding $300 \mathrm{~g}$ of whole plants to $500 \mathrm{ml}$ vinegar (4\% acetic acid) and stored at $4^{\circ} \mathrm{C}$. Samples were taken for analysis after 3, 6, and 9 days. The pickled samples were then dried at $60^{\circ} \mathrm{C}$ and ground to a powder.

\subsection{Sensory Evaluation}

Sensory evaluation of biscuits was done by ten experienced panelists. Each panelist was asked to assign a numerical value between 0 and 10 for following attributes: scores ranging from 1 to 10 which represented dislike extremely to the like extremely. The sensory attributes evaluated were color, odor, taste, texture, appearance and overall acceptability [25].

\subsection{Statistical Analysis}

Data was subjected to analysis of variance by one-way ANOVA using Sigma Stat (v.3.5. Systat Software Inc.). The significant difference between the means of treatments was determined at the $P \leq 0.05$ level by Duncan's new multiple range test [26].

\subsection{Results and Discussion}

\subsection{Proximate Chemical Composition of Purslane Powder}

Fresh purslane contains $91.7 \%$ water. The composition of the dry powder is shown in Table 1.

Table 1. Proximate Chemical Composition (\% on dry mass basis) of Purslane Powder

\begin{tabular}{llllll}
$\begin{array}{l}\text { Composition } \\
\text { (\%) }\end{array}$ & Protein & Fat & Ash & Fiber & Carbohydrates \\
Purslane & 5.64 & 5.30 & 23.42 & 16.03 & 49.61 \\
\hline
\end{tabular}


Our sample had much lower crude protein content (5.30\% vs. $23.47 \%)$, higher fiber content (16.03\% vs. $8 \%$ ), and higher carbohydrate content (49.61\% vs. $40.67 \%$ ) compared to [6], where the purslane leaves with stem contained comparable amount of ash (22.66\%) and carbohydrates (40.67\%). High crude protein (17.9\%), crude fiber (20.3\%), and fat (5.6\%) were reported by another group also [27].

\subsection{Analysis of Minerals of Purslane Powder}

Data in Table 2 shows the concentrations of the analyzed mineral constituents of purslane powder.

Table 2. Minerals content ( $\mathrm{mg} / \mathbf{1 0 0} \mathrm{g})$ of purslane powder.

\begin{tabular}{llllllllll}
\hline $\begin{array}{l}\text { Minerals } \\
(\mathbf{m g} / \mathbf{1 0 0} \mathbf{g})\end{array}$ & $\mathbf{N a}$ & $\mathbf{K}$ & $\mathbf{C a}$ & $\mathbf{M g}$ & $\mathbf{C u}$ & $\mathbf{F e}$ & $\mathbf{Z n}$ & $\mathbf{M n}$ & $\mathbf{P}$ \\
purslane & 242.0 & 4694.0 & 1238.1 & 730.31 & 1.67 & 79.4 & 0.93 & 1.96 & 225.0 \\
\hline
\end{tabular}

These results are in harmony with earlier reports [27, 28], which reported that the mineral composition of dried powder $(\mathrm{mg} / 100 \mathrm{~g})$ of Portulaca oleracea was very high in calcium (1178), potassium (4191.52), magnesium (942.5), and iron (155.94). However, [6] reported much lower mg/100 gm values, for example for $\mathrm{K}$ (14.71), $\mathrm{Na}$ (7.17), $\mathrm{Ca}$ (18.71), and Fe (0.48), but a higher value for $\mathrm{Zn}$ (3.02). A third study looked at ten elements and found $\mathrm{K}$ (241.03) Ca (834.21), Na (8.37), Mg (541.38), Cu (1.59), Zn (5.85), Fe (17.03), Mn (3.66), Cr (0.11), and Ni (0.07) [29]. Others found Ca (110), Mg (39), K (3400), Na (266.5), Fe (115), Zn (28), Cu (3.2), Mn (12), Co (0.32), Li (0.15), $P$ (532.5) [30]. These differences may be due to the local availability of these minerals, since plants are opportunistic in taking up certain soluble minerals. The mineral composition of the locally available crop determines what mineral nutritional benefits are imparted on the food additive.

The importance of these minerals is due to their physiological effects in the human body, such as calcium and phosphorous for bone health and iron for blood and muscles. The data show that there is great variation of the concentration of certain minerals in purslane powder and consequently, in the physiological benefits it provides.

\subsection{Identification and Determination of Phenolic Compounds of Purslane Powder}

The phenolic compounds that were found and measured shown in Table 3. Nineteen compounds of phenolic acids were identified in the purslane powder extract.

Table 3. Identification and determination of phenolic compounds of purslane powder; GAE= Gallic acid equivalent

\begin{tabular}{ll}
\hline Phenolic compounds & Purslane (ppm) \\
Pyrogallol & 142.08 \\
Gallic acid & 11.94 \\
4-Aminobenzoic acid & 2.90 \\
Protocatechuic acid & 33.57 \\
Catechin & 14.05 \\
Catechol & 165.8 \\
Epicatechin & 14.27 \\
p-Hydroxybenzoic acid & 18.53 \\
\hline
\end{tabular}




\begin{tabular}{ll}
\hline Chlorogenic acid & 14.34 \\
p-Vanillic acid & 41.2 \\
Caffeic acid & 9.43 \\
p-Coumaric acid & 6.55 \\
Ferulic acid & 42.95 \\
o-Vanillic acid & 298.31 \\
$\alpha$-Coumaric acid (o-coumaric acid) & 6.74 \\
Ellagic acid & 893.87 \\
3,4,5-Methoxycinnamic acid & 73.67 \\
Cinnamic acid & 0.96 \\
Salicylic acid & 57.33 \\
Total phenols (mg/100g GAE) & 193.22 \\
Radical scavenging activity (RSA \%) & 87.29 \\
\hline
\end{tabular}

Ellagic acid was the dominant one (found at 893.87 ppm), followed by o-vanillic acid (298.31 ppm) and catechol (165.8 ppm). The least abundant phenolic acids were cinnamic acid $(0.96 \mathrm{ppm}), 4$-aminobenzoic acid ( $2.90 \mathrm{ppm})$, and p-coumaric acid $(6.55 \mathrm{ppm})$. Total phenolic compound levels contribute to the radical scavenging activity. Total phenolics were $193.22 \mathrm{mg} \mathrm{GAE} / 100 \mathrm{~g}$ dry mass, and radical scavenging activity of purslane powder was and $87.28 \%$.

Purslane contains substances with potent pharmacological actions such as hepatoprotective, anti-inflammatory, analgesic, anti-ulcer, antitumor, wound healing, anti-cancer, neuropharmacological, neuroprotective, bronchodilatory, antidiabetic, antioxidant, antihypertensive, antibacterial, antiviral, and many others [2, 31-47]. Lipids, flavonoids, and alkaloids have been reported to occur in purslane $[43,48-51]$. With respect to the activities of phenolic compounds, those actions are anti-cancer, anti-inflammatory, and anti-atherosclerosis activities [5255].

\subsection{Fatty Acid Composition}

Fatty acid composition of purslane powder is given in Table (4). The most abundant fatty acids in the lipid fraction of purslane powder are linolenic acid (40.4\%) and linoleic acid (19.7\%). On the other hand, stearic acid constituted only $3.59 \%$ of the total fatty acids.

Table 4. Fatty Acid Composition of Purslane Powder

\begin{tabular}{|c|c|c|c|c|c|c|}
\hline Fatty acids & $\begin{array}{l}\text { Linolenic } \\
\text { acid (18:3) }\end{array}$ & $\begin{array}{l}\text { Linoleic } \\
\text { acid (18:2) }\end{array}$ & $\begin{array}{l}\text { Oleic acid } \\
(18: 1)\end{array}$ & $\begin{array}{l}\text { Palmitic } \\
\text { acid }(16: 0)\end{array}$ & $\begin{array}{l}\text { Palmitoleic } \\
\text { acid (16:1) }\end{array}$ & $\begin{array}{l}\text { Stearic acid } \\
(18: 0)\end{array}$ \\
\hline $\begin{array}{l}\text { Composition } \\
\text { (\%) }\end{array}$ & 40.4 & 19.7 & 7.32 & 13.76 & 15.23 & 3.59 \\
\hline
\end{tabular}

It is notable that purslane contains a high level of omega-3 fatty acid, close to what was reported by [9], who found that linolenic acid ranged between 24.48 and $39.06 \%$, linoleic ranged between 4 and $6.31 \%$, and palmitic acid was $16.34 \%$, and oleic acid was $9.59 \%$. 


\subsection{The Effects of Cooking and Pickling Parameters on Oxalate Content}

The effects of the cooking process on the soluble and insoluble oxalate content of the raw purslane are shown on Figs. 1, 2 and 3, compared to the raw purslane (control). The cooking process was carried out in tap water for different periods $\left(5,10,15\right.$, and $20 \mathrm{~min}$.) and at various temperatures $\left(60,80\right.$, and $\left.100^{\circ} \mathrm{C}\right)$. The cooking water is poured off, so purslane prepared this way is blanched. The results indicated that, soluble portion of the total oxalate in purslane cooked (blanched) at $60^{\circ} \mathrm{C}$ was $45.8,42.2,38.2$ and $34.6 \%$ of the total oxalate after $5,10,15$ and 20 minutes, respectively, compared to the control (47.8\%).

The soluble portion of the total oxalate in purslane cooked (blanched) at $80{ }^{\circ} \mathrm{C}$ was $42.0,39.2,30.9$ and $19.8 \%$ of the total oxalate after 5, 10, 15 and 20 min., respectively. The soluble portion of total oxalates in purslane cooked (blanched) at $100{ }^{\circ} \mathrm{C}$ was lower than that at 60 and $80^{\circ} \mathrm{C}$. The cooking process significantly $(p<0.05)$ reduced the soluble portion of the total oxalate content of raw purslane. It was clear that increasing the temperature of cooking and the cooking time decreased the soluble oxalate content.

The increase of insoluble oxalate during cooking varied greatly, ranging from 0 to $84.16 \%$. Soluble sources of oxalate appear to be better absorbed than insoluble sources [56]. Furthermore, these results agree well with those of [57], who reported that boiling purslane for 25 minutes and draining the water resulted in a significant decrease of soluble oxalate levels, however, this treatment also resulted in an undesirable loss of total solids and valuable nutrients. Boiling for such a long time likely will not allow purslane to retain its health benefits. However, it was reported that oxalates in purslane can be reduced without excessive losses of minerals when the plant was boiled in a $3 \%$ salt solution [57].

The effects of the pickling process on oxalate content of purslane are shown in Fig. 4. Compared to raw purslane control, the pickling process was carried out in tap water for different periods (3, 6 and 9 days). Data cleared that, the soluble oxalate in the pickled purslane was $36.2,25.6$ and $14.39 \%$ of the total oxalate for 3,6 and 9 days, respectively, compared with control (47.8\%).

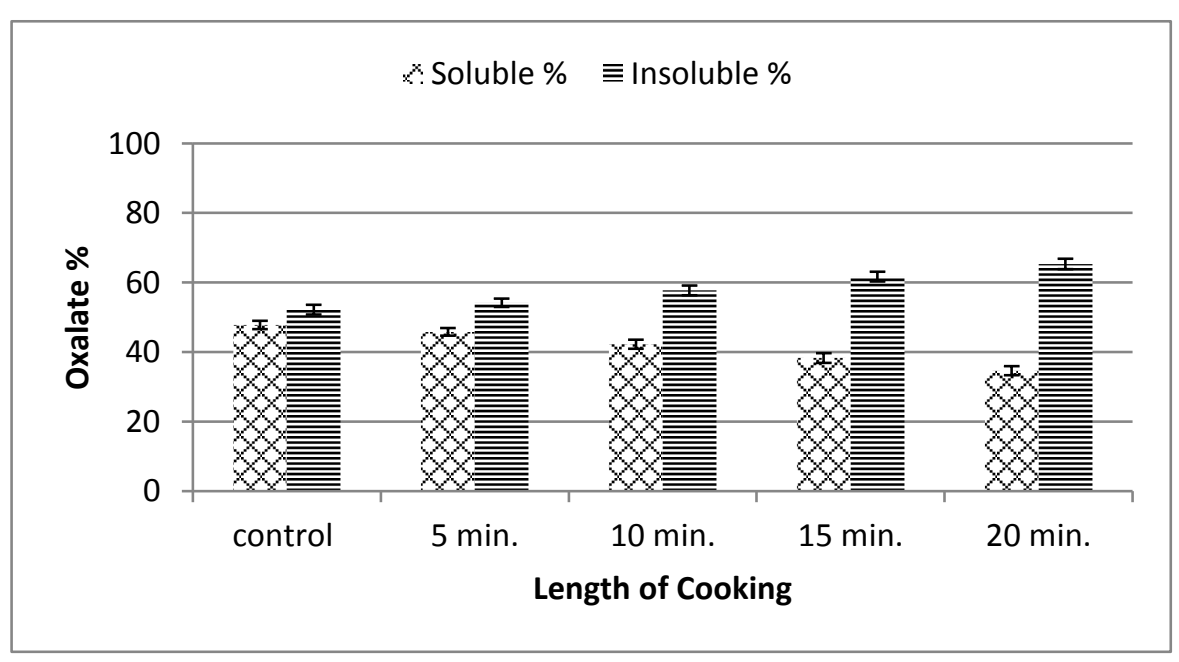

Fig. 1. Effect of cooking process at $60^{\circ} \mathrm{C}$ on the soluble portion of the total oxalate content 


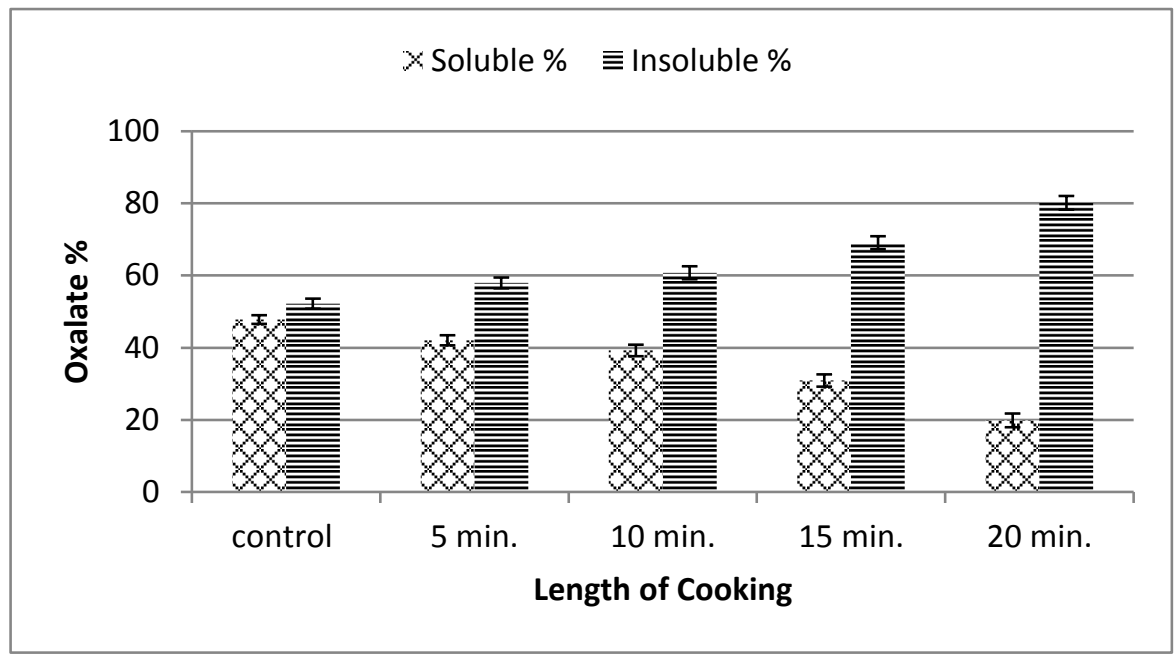

Fig. 2. Effect of cooking process at $80^{\circ} \mathrm{C}$ on the soluble portion of the total oxalate content

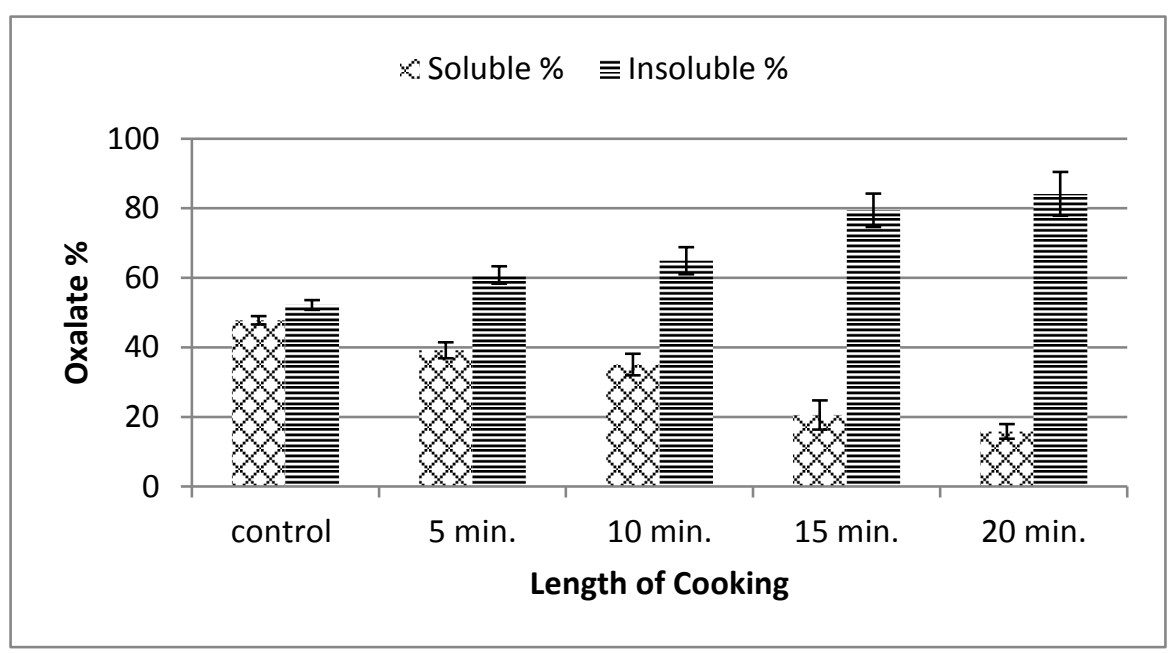

Fig. 3. Effect of cooking process at $100{ }^{\circ} \mathrm{C}$ on the soluble portion of the total oxalate content

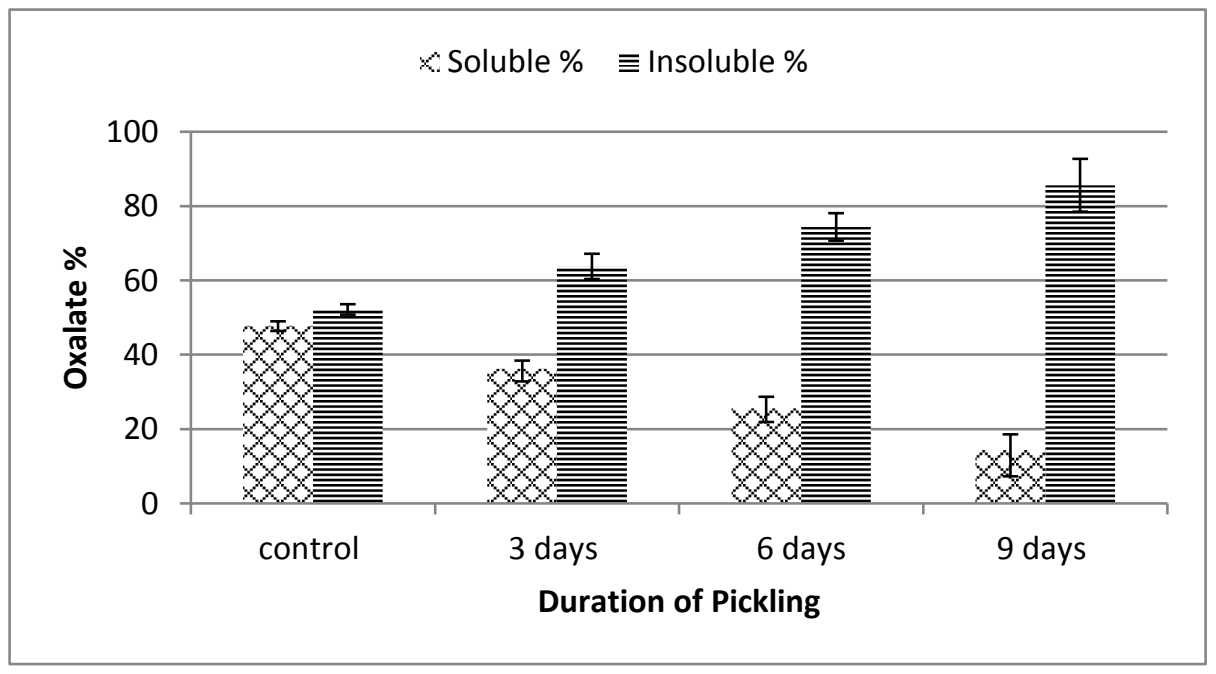

Fig. 4. Effects of the pickling process on the soluble portion of total oxalate content of purslane 


\subsection{Organoleptic Evaluation of Biscuits Made with Purslane Powder at Different Levels}

The results of the sensory evaluation expressed as acceptability score of wheat flour biscuits with added purslane powder containing the lowest percentage of soluble oxalate (pickling for 9 days) at levels of 3, 6 and $9 \%$ are presented in Table 5. Highest acceptability was found for the 3\% purslane powder substituted for wheat flour, followed by $6 \%$ and $9 \%$, compared to the control. The results shown in Table 5 indicate that biscuits with purslane had enhanced sensory scores, in comparison to control. There were no significant differences between the control and those fortified with $3 \%, 6 \%$, or $9 \%$. Therefore, the most acceptable of biscuits were those that contained $3 \%$ purslane powder.

Table 5. Sensory evaluation of biscuit fortified with purslane powder expressed as acceptability scores

\begin{tabular}{lllllll}
\hline $\begin{array}{l}\text { Purslane } \\
\text { powder }\end{array}$ & Color & Taste & Odor & Texture & Appearance & $\begin{array}{l}\text { Overall } \\
\text { acceptability }\end{array}$ \\
& & & & & & \\
Control $^{*}$ & $8.5 \pm 1.1^{\mathrm{a}}$ & $8.2 \pm 0.92^{\mathrm{a}}$ & $7.9 \pm 0.44^{\mathrm{ab}}$ & $8.7 \pm 1.0^{\mathrm{ab}}$ & $8.6 \pm 1.1^{\mathrm{a}}$ & $8.3 \pm 1.0^{\mathrm{b}}$ \\
$3 \%$ & $8.6 \pm 1.0^{\mathrm{a}}$ & $8.2 \pm 0.88^{\mathrm{a}}$ & $8.1 \pm 0.74^{\mathrm{a}}$ & $8.9 \pm 0.65^{\mathrm{a}}$ & $8.7 \pm 1.0^{\mathrm{a}}$ & $8.7 \pm 1.1^{\mathrm{a}}$ \\
$6 \%$ & $8.6 \pm 1.0^{\mathrm{a}}$ & $8.3 \pm 1.0^{\mathrm{a}}$ & $8.1 \pm 1.0^{\mathrm{a}}$ & $8.6 \pm 0.89^{\mathrm{b}}$ & $8.6 \pm 0.48^{\mathrm{a}}$ & $8.6 \pm 1.0^{\mathrm{a}}$ \\
$9 \%$ & $8.5 \pm 1.0^{\mathrm{a}}$ & $8.3 \pm 1.1^{\mathrm{a}}$ & $8.2 \pm 1.1^{\mathrm{a}}$ & $8.5 \pm 1.0^{\mathrm{b}}$ & $8.5 \pm 0.92^{\mathrm{ab}}$ & $8.5 \pm 1.0^{\mathrm{ab}}$ \\
\hline
\end{tabular}

*: without adding of purslane powder.

Means with different superscripts (small letters in the same column) are significantly different at $(P \leq 0.05)$.

\subsection{Chemical Composition of Biscuits Fortified with Purslane Powder}

Since purslane has a high nutritional value owing to its high protein, fat, ash and fiber contents, it was incorporated in the currently used biscuits formula. The chemical compositions of biscuits fortified with purslane are shown in Table (6). The addition of purslane significantly increased the protein, fat, fiber and content. Increasing the fortification level of purslane powder directly increased the protein, fat, fiber and ash contents of the biscuits. This is mainly due to the higher protein, fat, fiber, and levels in purslane powder compared wheat flour. The biscuits fortified with $9 \%$ purslane had the highest percent of protein, fat, ash and fiber contents (13.23, 21.77, 1.59 and $5.27 \%$, respectively), compared to control.

Table 6. Effect of chemical composition of biscuit fortified with purslane powder (\% on dry mass basis)

\begin{tabular}{lllll}
\hline \multirow{2}{*}{ Components } & \multicolumn{4}{l}{ Biscuit fortified with purslane powder } \\
& Control & $\mathbf{3} \%$ & $\mathbf{6} \%$ & $\mathbf{9} \%$ \\
Moisture & $4.60 \pm 0.34$ & $4.63 \pm 0.24$ & $4.78 \pm 0.18$ & $5.18 \pm 0.50$ \\
Crude protein & $11.43 \pm 0.47$ & $11.98 \pm 0.71$ & $12.88 \pm 0.81$ & $13.23 \pm 0.87$ \\
Fat & $19.92 \pm 1.1$ & $20.25 \pm 1.0$ & $21.11 \pm 1.2$ & $21.77 \pm 1.0$ \\
Ash & $0.92 \pm 0.04$ & $0.97 \pm 0.17$ & $1.27 \pm 0.04$ & $1.59 \pm 0.32$ \\
Crude fiber & $2.35 \pm 0.12$ & $2.93 \pm 0.35$ & $3.95 \pm 0.19$ & $5.27 \pm 0.58$ \\
Carbohydrates* & $65.38 \pm 1.4$ & $63.87 \pm 1.3$ & $60.79 \pm 1.1$ & $58.14 \pm 1.2$ \\
\hline
\end{tabular}


*: calculated by difference

\subsection{Fatty Acid Composition of Biscuits}

Fatty acid analysis of the biscuits results indicated an increase of all unsaturated fatty acids, such as linolenic acid ( $\omega-3)$ and linoleic acid, compared to control (Table 7). Purslane contains high amounts of linolenic acid ( $\omega$ 3), linoleic acid being the second in abundance (Table 4).

Purslane has been reported to contain high amounts of omega-3 (C18:3n3) [58] and omega-6 (C18:2n6) unsaturated fatty acids [59]. Omega-3 ( $\omega$-3) fatty acids have been reported to be essential for normal growth and development and may play an important role in the prevention and treatment of coronary artery disease, hypertension, diabetes, arthritis, cancer, and other inflammatory and autoimmune disorders [60-62].

Table 7. Fatty Acid Composition (\% on dry mass basis) of Biscuits Fortified with Purslane Powder

\begin{tabular}{lllllll}
\hline $\begin{array}{l}\text { Purslane } \\
\text { powder }\end{array}$ & $\begin{array}{llllll}\text { Patty acids } \\
\mathbf{( 1 6 : 0 )}\end{array}$ & $\begin{array}{l}\text { Stearic } \\
\mathbf{( 1 8 : 0 )}\end{array}$ & $\begin{array}{l}\text { Palmitoleic } \\
\mathbf{( 1 6 : 1 )}\end{array}$ & $\begin{array}{l}\text { Oleic } \\
\mathbf{( 1 8 : 1 )}\end{array}$ & $\begin{array}{l}\text { Linoleic } \\
\mathbf{( 1 8 : 2 )}\end{array}$ & $\begin{array}{l}\text { Linolenic } \\
\mathbf{( 1 8 : 3 )}\end{array}$ \\
Control & 31.27 & 2.49 & 0.44 & 38.31 & 14.20 & 0.65 \\
$\mathbf{3} \%$ & 31.89 & 2.75 & 0.49 & 38.85 & 14.45 & 0.93 \\
$\mathbf{6} \%$ & 32.19 & 2.92 & 0.62 & 39.55 & 14.64 & 1.79 \\
$\mathbf{9 \%}$ & 32.44 & 3.23 & 0.83 & 39.95 & 14.96 & 2.41 \\
\hline
\end{tabular}

Optimized technologies for functional food products fortified with purslane have been reported [63, 64]. Dehydration has an impact on retention of bioactive molecules and antioxidant activity of purslane [65].

\subsection{Conclusion}

Purslane (Portulaca oleracea) could be more widely used since it is a good source of minerals, and antioxidants, especially for functional food and nutraceutical applications. Also, the results confirm that optimized cooking and pickling processes reduce the soluble oxalate content of purslane. In addition, the consumption of such properly cooked or pickled purslane would supply a valuable source of omega-3 fatty acids and other nutrients.

\subsection{Conflicts of Interest}

None.

\subsection{Funding Statement}

This research was supported by the Faculty of Agriculture, Kafr El Sheikh University.

\subsection{References}

1. Radhakrishnan, R., M.N.M. Zakaria, M.W. Islam, H.B. Chen, M. Kamil, et al., Neuropharmacological actions of Portulaca oleracea L v. sativa (Hawk). Journal of Ethnopharmacology, 2001. 76(2): 171-176. 
2. Wang, H., Treatment of diabetes mellitus with single Chinese medicinal herb Portulaca oleracea. Zhejiang J TCM, 1990. 25(11): 516-516.

3. Awad, N., Lipid content and antimicrobial activity of phenolic constituents of cultivated Portulaca oleracea L. Bull. Fac. Pharm. Cairo Univ., 1994. 32(1): 137-142.

4. Masoodi, M., B. Ahmad, S. Mir, B. Zargar, and N. Tabasum, Portulaca oleracea L. A Review. Journal of Pharmacy Research, 2011. 4(9): 3044-3048.

5. Alam, M.A., A.S. Juraimi, M.Y. Rafii, A.A. Hamid, F. Aslani, et al., A Comparison of Yield Potential and Cultivar Performance of 20 Collected Purslane (Portulaca oleracea L.) Accessions Employing Seeds vs. Stem Cuttings. Journal of Agricultural Science and Technology, 2014. 16: 1633-1648.

6. Aberoumand, A., Nutritional evaluation of edible Portulaca oleracea as plant food. Food Analytical Methods, 2009. 2(3): 204-207.

7. Lim, Y.Y. and E.P.L. Quah, Antioxidant properties of different cultivars of Portulaca oleracea. Food Chemistry, 2007. 103(3): 734-740.

8. Jiao, Z., D. Liu, P. Wang, and L. Xiang, Determination of total polyphenols in Portulaca oleracea from various habitats by colorimetric method. World Phytomedicines (Drugs and Clinic), 2014. 2014(7): 745748.

9. Oliveira, I., P. Valentao, R. Lopes, P.B. Andrade, A. Bento, et al., Phytochemical characterization and radical scavenging activity of Portulaca oleraceae L. leaves and stems. Microchemical Journal, 2009. 92(2): 129-134.

10. Guo, Z., P. Liu, and C. Fu, Determination of low molecular weight carboxylic acids in purslane by ion exclusion chromatography. Chinese Journal of Chromatography 1996. 14(1): 50-52.

11. Poeydomenge, G.Y. and G.P. Savage, Oxalate content of raw and cooked purslane. Journal of Food Agriculture \& Environment, 2007. 5(1): 124-128.

12. Liu, L.X., P. Howe, Y.F. Zhou, Z.Q. Xu, C. Hocart, et al., Fatty acids and $\beta$-carotene in Australian purslane (Portulaca oleracea) varieties. Journal of Chromatography A, 2000. 893(1): 207-213.

13. Huang, X., R. Zhang, Q. Li, Y. Zhang, and C. Song, Research progress on the biological functions of Portulaca oleracea. Journal of Jilin Medical College, 2010. 2010(6): 165-167.

14. Simopoulos, A.P., Omega-3 fatty acids and antioxidants in edible wild plants. Biological Research, 2004. 37(2): 263-277.

15. Mathams, R.H. and A.K. Sutherland, The oxalate content of some Queensland pasture plants. Queensland Jour Agric Sci, 1952. 9((4)): 317-334.

16. Moreau, A.G. and G.P. Savage, Oxalate content of purslane leaves and the effect of combining them with yoghurt or coconut products. Journal of Food Composition and Analysis, 2009. 22(4): 303-306.

17. Gonnella, M., M. Charfeddine, G. Conversa, and P. Santamaria, Portulaca: from weed to function as a foodstuff. Colture-Protette, 2005. 34(49-55). 
18. Noonan, S.C. and G.P. Savage, Oxalate content of foods and its effect on humans. Asia Pacific J. Clin. Nutr., 1999. 8: 64-74.

19. Judprasong, K., S. Charoenkiatkul, P. Sungpuag, K. Vasanachitt, and Y. Nakjamanong, Total and soluble oxalate contents in Thai vegetables, cereal grains and legume seeds and their changes after cooking. Journal of Food Composition and Analysis, 2006. 19(4): 340-347.

20. Aper, P. and V. Bezaro, Manual Decettes Boulangeres et Pâtissieres. 1990: L'École de Boulangerie du Caire. 118.

21. Horwitz, W., Official methods of analysis of AOAC International. 2002, Gaithersburg, Md.: AOAC International.

22. Radwan, S.S., Coupling of 2-dimensional thin-layer chromatography with gas chromatography for quantitative analysis of lipd classes and their constituent fatty acids. Journal of Chromatographic Science, 1978. 16(11): 538-542.

23. Goupy, P., M. Hugues, P. Boivin, and M.J. Amiot, Antioxidant composition and activity of barley (Hordeum vulgare) and malt extracts and of isolated phenolic compounds. Journal of the Science of Food and Agriculture, 1999. 79(12): 1625-1634.

24. Vallverdú-Queralt, A., J. Regueiro, M. Martinez-Huelamo, J.F. Rinaldi Alvarenga, L.N. Leal, et al., $A$ comprehensive study on the phenolic profile of widely used culinary herbs and spices: Rosemary, thyme, oregano, cinnamon, cumin and bay. Food Chemistry, 2014. 154: 299-307.

25. Ramadhan, K., N. Huda, and R. Ahmad, Physicochemical characteristics and sensory properties of selected Malaysian commercial chicken burgers. International Food Research Journal, 2011. 18: 13491357.

26. Steel, R.G.D. and J.H. Torrie, Principles and procedures of statistics : a biometrical approach. 1981, Auckland: McGraw-Hill.

27. Obied, W.A., E.N. Mohamoud, and O.S.A. Mohamed, Portulaca oleracea (purslane): nutritive composition and clinico-pathological effects on Nubian goats. Small Ruminant Research, 2003. 48(1): 31-36.

28. Hanan, A.A., M.H. Sobhy, A.A. Kawkab, K.A. Azza, A.R. Zeinab, et al., Chemical and remedial effects of purslane (Portulaca oleracea) plant. Life Science Journal, 2014. 11(6): 31-42.

29. Ma, Y. and C. Wang, Determination of Ten Inorganic Elements in Portulaca oleracea L. . Food and Drug, 2014. 2014: 359-360.

30. Tan, L., Q. Zhou, J. Yin, and et al., Analysis of nutrient composition of Portulaca oleracea L. Its development and utilization. China Wild Plant Resources, 2000. 19(2): 49-50.

31. Parry, O., F. Okwuasaba, and C. Ejike, Preliminary Clinical Investigation into the muscle-relaxant actions of an aqueous extract of Portulaca oleracea applied topically. Journal of Ethnopharmacology, 1987. 21(1): 99-106. 
32. He, S., Z. Fan, P. Li, and et al., Experimental studies on anti-atherosclerosis effect of wild Portulaca oleracea. Acta Nutrimenta Sinica, 1997. 19(6): 59-63.

33. He, S., T. Liu, M. You, and et al., Preventive and therapeutic effect of Portulaca oleracea on experimental hyperlipidemia in rabbits. Chinese Traditional and Herbal Drugs, 1997. 28(4): 221-223.

34. Chan, K., M.W. Islam, M. Kamil, R. Radhakrishnan, M.N.M. Zakaria, et al., The analgesic and antiinflammatory effects of Portulaca oleracea L. subsp sativa (Haw.) Celak. Journal of Ethnopharmacology, 2000. 73(3): 445-451.

35. Chen, J., Y.P. Shi, and J.Y. Liu, Determination of noradrenaline and dopamine in Chinese herbal extracts from Portulaca oleracea L. by high-performance liquid chromatography. Journal of Chromatography A, 2003. 1003(1-2): 127-132.

36. Rashed, A.N., F.U. Afifi, and A.M. Disi, Simple evaluation of the wound healing activity of a crude extract of Portulaca oleracea L. (growing in Jordan) in Mus musculus JVI-1. Journal of Ethnopharmacology, 2003. 88(2-3): 131-136.

37. Shen, L. and F. Lu, Effects of Portulaca oleracea on Insulin Resistance in Rats with Type 2 Diabetes Mellitus. Chinese Journal of Integrative Medicine, 2003. 9(4): 289-290.

38. Yang, M., S. Zhang, Z. Tang, and B. Cui, Influence of different preparing procedure on the bacteriostasis of Portulaca oleracea L. In vitro Journal of Traditional Chinese Veterinary Medicine, 2006. 2006(5): 29-30.

39. Dong, C.-X., K. Hayashi, J.-B. Lee, and T. Hayashi, Characterization of Structures and Antiviral Effects of Polysaccharides from Portulaca oleracea L. Chemical \& Pharmaceutical Bulletin, 2010. 58(4): 507 510.

40. Dkhil, M.A., A.E.A. Moniem, S. Al-Quraishy, and R.A. Saleh, Antioxidant effect of purslane (Portulaca oleracea) and its mechanism of action. Journal of Medicinal Plants Research, 2011. 5(9): 1589-1593.

41. Jing, S., Y. Cai, and L. Tong, The Preparation Technology of Portulaca oleracea L. Liquid and Its Preliminary Pharmacology Tests. The Food Industry, 2014. 2014(12): 123-126.

42. Wu, J., Y. Li, G. Wu, X. Han, C. Wang, et al., Research of preparation and structural characterization of polysaccharides from Portulaca oleracea L. . Science and Technology of Food Industry, 2014. 35(5): 374-375.

43. Chen, L., W. He, K. Tao, Q. Cao, F. Li, et al., Changes of Antioxidant Compounds and Antioxidant Activities in Portulaca oleracea L. During Different Harvest Time. Northern Horticulture, 2015. 2015(6): 157-160.

44. Ai, H., W. Zhang, Q. Xia, and H. Tang, Extraction and Bioactivity of Polysaccharide of Portulaca oleracea L. . Shandong Chemical Industry, 2015. 2015: 40-46.

45. Noreen, S., I. Hussain, M.I. Tariq, B. Ijaz, S. Iqbal, et al., Portulaca oleracea L. as a Prospective Candidate Inhibitor of Hepatitis C Virus NS3 Serine Protease. Viral Immunology, 2015. 28(5): 282-289. 
46. Sumathi, T. and J. Christinal, Neuroprotective Effect of Portulaca oleraceae Ethanolic Extract Ameliorates Methylmercury Induced Cognitive Dysfunction and Oxidative Stress in Cerebellum and Cortex of Rat Brain. Biological Trace Element Research, 2016. 172(1): 155-165.

47. Xu, W. and X. Ying, Isolation and Identification of Hydroxydihydrobovolide in Portulaca oleracea L. . Liaoning Journal of Traditional Chinese Medicine, 2017. 44(1): 122-124.

48. Wang, Z., X. Li, and C. Xuan, Determination of Alkaloids in Portulaca oleracea L. . Journal of Taiyuan University of Technology, 2001. 2001(2): 197-198,212.

49. Wei, S. and Z. Wang, Determination of Flavonoids in Portulaca oleracea L. . Chinese Journal of Spectroscopy Laboratory, 2003. 20(1): 128-129.

50. Yang, Q., H. Ye, H. Tang, K. Chen, L. Chen, et al., Aliphatic compounds from Portulaca oleracea L. . Chinese Traditional Patent Medicine, 2016. 2016(3): 583-587.

51. Li, C., L. Xu, and X. Xing, Isolation and Identification of $\beta$-carboline from Portulaca oleracea L. . Journal of Liaoning College of Traditional Chinese Medicine, 2017. 2017(2): 44-46.

52. Havsteen, B.H., The biochemistry and medical significance of the flavonoids. Pharmacology \& Therapeutics, 2002. 96(2-3): 67-202.

53. Sun, J., Chemical Constituents from Portulaca oleracea L. Journal of Chinese Pharmaceutical Sciences (English Edition) 13(4): 291-292. Journal of Chinese Pharmaceutical Sciences (English Edition), 2004. 13(4): 291-292.

54. Zhou, Y., J. Luo, G. Zhang, G. Zhang, and C. Zhang, Effects of Portulaca oleracea $L$ on expression of IFN- $\gamma$ and IL-10 cytokine in rats with experimental colitis. Chinese Pharmacological Bulletin, 2008. 24(8): 1113-1114.

55. Duan, H., L. Zhao, and H. Chen, Chemical Constituents in Portulaca oleracea Journal of Hebei University (Natural Science Edition), 2011. 31(4): 389-392.

56. Chai, W.W. and M. Liebman, Effect of different cooking methods on vegetable oxalate content. Journal of Agricultural and Food Chemistry, 2005. 53(8): 3027-3030.

57. Tabekhia, M.M., R.B. Toma, and A.R. Elmahdy, Effect of Egyptian cooking methods on total, free oxalates and mineral contents of 2 leafy, green, vegetables (Jews mellow and purslane). Nutrition Reports International, 1978. 18(5): 611-616.

58. Chen, Y., Z. Shen, and X. Chen, Evaluation of free radicals scavenging and immunity-modulatory activities of Purslane polysaccharides. International Journal of Biological Macromolecules, 2009. 45(5): 448-452.

59. Zhou, Y. and D. Zhang, Portulaca oleracea and $\omega-3$ multivalent unsaturated fatty acids. World Notes on Plant Medicine, 1995. 10(6): 247-250.

60. Simopoulos, A.P., Essential fatty acids in health and chronic diseases. Forum of nutrition, 2003. 56: 67-70. 
61. Simopoulos, A.P., Evolutionary aspects of omega-3 fatty acids in the food supply. Prostaglandins Leukotrienes and Essential Fatty Acids, 1999. 60(5-6): 421-429.

62. Simopoulos, A.P. and N. Salem, Purslane - A terrestrial source of omega-3-fatty acids. New England Journal of Medicine, 1986. 315(13): 833-833.

63. Zheng, H., J. Wang, and S. Wang, Preparation of Portulaca oleracea Vermicelli. Food Science and Technology, 2002. 2002(5): 57-58.

64. Liang, Y., Development of Clear Purslane Functional Beverage. Hubei Agricultural Sciences, 2014. 53(7): 1627-1630.

65. Shanker, N. and S. Debnath, Impact of dehydration of purslane on retention of bioactive molecules and antioxidant activity. Journal of Food Science and Technology-Mysore, 2015. 52(10): 6631-6638. 